UDC [612.66+616-092] : 577.15

\title{
OXIDATIVE STRESS AND THE ENZYME SYSTEM OF ALDEHYDE CATABOLISM IN THE MUSCLE MITOCHONDRIA OF IMMOBILIZED PUBERTAL RATS
}

\author{
AMJAD HAMDALLAH ${ }^{1}$, V. V. DAVYDOV², V. N. SHVETS 3 \\ ${ }^{1}$ V. N. Karazin Kharkiv National University, Ukraine; \\ ${ }^{2} S U$ Institute of Children and Adolescent Health Care, National Academy \\ of Medical Science of Ukraine; \\ ${ }^{3}$ Zaporizhzhia State Medical University, Ukraine; \\ e-mail: vaddavydov@mail.ru
}

The aim of the work is to find out peculiarities in manifestation of oxidative stress and to determine activity of enzymes, responsible for utilization of endogenous aldehydes in the mitochondrial fraction of the skeletal (femoral) muscle in pubertal rats during immobilization stress. Our study has shown that differently directed changes in the activity of mitochondrial aldehyde dehydrogenases and aldehyde reductases occur in the pubertal immobilized rats, that limits the catabolism effectiveness as regards carbonyl products of free radical oxidation in the muscle cells. Corroboration of the effect under consideration is an increased level of protein free radical oxidation products in the mitochondria of the skeletal muscle. On the basis of the obtained data the authors draw a conclusion about an increased sensitivity of the skeletal muscle to the oxidative stress impact due to modulation in the state of enzyme system, responsible for utilization of endogenous aldehydes in the mitochondria.

Key words: aldehyde dehydrogenase, aldehyde reductase, glutathione transferase, aldehydes, protein carbonyls, Schiff bases, pubertal age, oxidative stress, immobilization stress.

$\mathrm{W}$ e have shown earlier that organism sensitivity to oxidative stress increases in pubertal age [1, 2]. This may be one of the reasons of the increase of visceral pathology in teenagers [3]. Analyzing probable mechanisms of formation of this age phenomena, we should note that the role of messengers of cell damage under the oxidative stress belongs to cytotoxic carbonyl products of free-radical oxidation accumulated under the stress conditions [4]. Allowing for above stated, we may presume that the modulation of resistance to oxidative stress on the stage of puberty, among other things, is connected with age changes in utilization effectiveness of endogenous aldehydes in cells. The performed investigations in fact allowed revealing the shifts in activity of enzymes of catabolism of carbonyl products of free-radical oxidation in the heart of rats of pubertal age under conditions of immobilizing stress $[5,6]$. They promote a decrease of catabolism velocity of endogenous aldehydes in the myocardium and thus, predetermine the occurrence of heart stress damage. However, the question arises whether such shifts are specific for the heart muscle only, or they are general for other tissues in the pubertal age? Taking this into consideration, the investigation is aimed at clarifying specificity of oxidative stress manifestation and condition of fermentation system of utilization of endogenous aldehydes in mitochondrial fraction of skeletal (femoral) muscle in rats of pubertal age under immobilizing stress.

\section{Materials and Methods}

Forty male rats of Wistar line aged 1.5-months (rats in pubertal age) and 12-month rats (adult sexually mature ones) were used in the work. Animals of each age group, in turn, were divided into 2 subgroups: 1 - intact rats and 2 - rats subjected to immobilization stress. To reproduce immobilization stress the animals were tied to immovable block for 5 h daily during 2 days. The stress reproduction efficiency was estimated by the level of adrenalin in blood. As it is shown on Figure, after two-day immobilization a sharp increase of adrenalin in blood occurred in animals of two groups.

Rats were decapitated under light ether anesthesia; their femoral muscles were removed and im- 


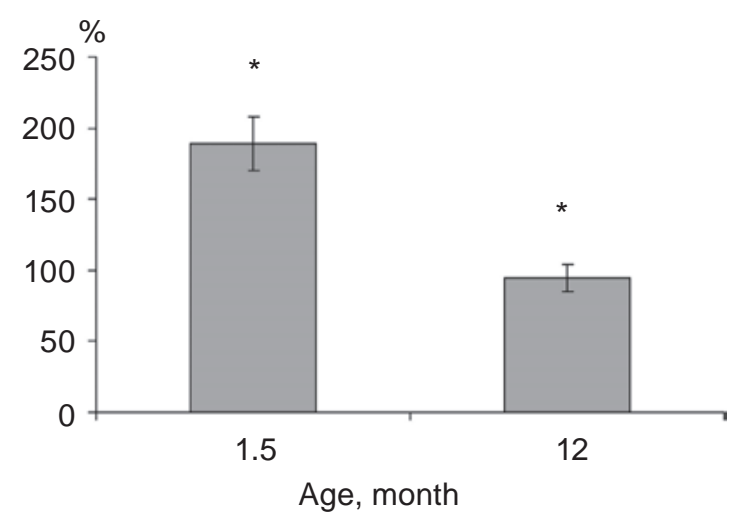

An increase of adrenaline concentration in blood of rats subjected to 2-day immobilization (results are expressed in \% to initial value. Adrenaline content in blood of intact rats of corresponding age groups is taken as $100 \%$ ). $* P<0.05$ to intact (6 animals in each group were used in research)

mediately put in chilled $0.9 \%$ solution of sodium chloride. After washing of blood, pieces of muscle tissue were cut small by scissors. Muscle slurry was mixed up in proportion $1: 3$ (mass:volume) with salt medium containing $0.05 \mathrm{M}$ Tris, $0.005 \mathrm{M}$ sulfate of magnesia and 0.001 MEDTA (pH 7.4), and homogenized during $3 \mathrm{~min}$ in Potter-Elvegame glass homogenizer with Teflon pestle. Homogenate was filtered through 4 layers of gauze and centrifuged at $1000 \mathrm{~g}$ during $10 \mathrm{~min}$. Supernatant was transferred to clean tubes and centrifuged at $10000 \mathrm{~g}$ during 20 min. The obtained precipitate was two times washed up in homogenization medium at $10000 \mathrm{~g}$ during $20 \mathrm{~min}$ and used as a mitochondrial fraction. All procedures of muscle homogenate fractioning were performed at $4-5^{\circ} \mathrm{C}$.

The activity of NAD-dependent aldehyde dehydrogenase (AlDG; 1.2.1.3) [7], NADH-dependent aldehyde reductase (AlR; 1.1.1.21) [8] and glutathione transferase (GT; 2.5.1.18) [9] was measured in mitochondrial fraction of the femoral muscle. The content of substances entering into positive reaction with 2-thiobarbituric acid (TBA-reactive substances; TBA+) [10], carbonylated proteins (CP) [11], and also fluorescent products of metabolism of Schiff bases (SB) type was studied in a series of special experiments in mitochondrial fraction. Fluorescence was measured at excitation wave length of $360 \mathrm{~nm}$ and emission wave length of $430 \mathrm{~nm}$. Protein content in samples was determined by the Loury method.

The obtained results underwent statistical processing with usage of Excel and "SPSS Statistics 17.0" software, with the help of Wilcoxon-MannWhitney non-parametric method. Data distinctions were considered valid under conditions of $P<0.05$.

\section{Results and Discussion}

The investigations have shown that contents of CP and SB increase by 74 and by $94 \%$, respectively, in mitochondrial fraction of the femoral muscle of 1.5-month old rats after long-lasting immobilization (Table). At the same time the concentration of TBAreactive substances in them remains unchanged.

Immobilization of 12-month old animals is accompanied by the decrease of SB level in mitochondrial fraction by 35\% compared with its original level. The content of TBA-reactive substances and

Content of free-radical oxidation products and catalytic activity of enzymes of endogenous aldehydes in mitochondrial fraction of femoral muscle of rats, which underwent prolonged immobilization $(M \pm m ; n=6)$

\begin{tabular}{|c|c|c|c|c|}
\hline \multirow{2}{*}{ Indicator } & \multicolumn{2}{|c|}{ 1.5-month old } & \multicolumn{2}{|c|}{ 12-month old } \\
\hline & intact & immobilized & intact & immobilized \\
\hline \multicolumn{5}{|c|}{ Content of products of free radical oxidation } \\
\hline $\mathrm{CP}, \mu \mathrm{mole} / \mathrm{mg}$ of protein & $0.77 \pm 0.12$ & $1.34 \pm 0.02 *$ & $1.90 \pm 0.27 * *$ & $1.39 \pm 0.29$ \\
\hline $\mathrm{TBA}+, \mu$ mole $/ \mathrm{mg}$ of protein & $0.16 \pm 0.03$ & $0.15 \pm 0.03$ & $0.25 \pm 0.02 * *$ & $0.24 \pm 0.03$ \\
\hline $\mathrm{SB}$, nmole/mg of protein & $0.49 \pm 0.06$ & $0.95 \pm 0.04^{*}$ & $0.94 \pm 0.03^{* *}$ & $0.59 \pm 0.06^{*}$ \\
\hline $\mathrm{SB} / \mathrm{TBA}+$ & $3.8 \pm 0.3$ & $7.5 \pm 1.2^{*}$ & $4.2 \pm 0.3$ & $2.4 \pm 0.4^{*}$ \\
\hline \multicolumn{5}{|c|}{ Enzymes of catabolism activity } \\
\hline AlDG, nmole/mg of protein $\cdot \min$ & $1.3 \pm 0.2$ & $4.2 \pm 0.7^{*}$ & $10.4 \pm 1.2^{* *}$ & $* 20.9 \pm 3.1$ \\
\hline AlR, nmole/mg of protein $\cdot \min$ & $1.7 \pm 0.5$ & $1.0 \pm 0.1^{*}$ & $3.7 \pm 0.6^{* *}$ & $4.7 \pm 1.0$ \\
\hline GT, nmole/mg of protein $\cdot \min$ & $1.3 \pm 0.1$ & $1.5 \pm 0.2$ & $1.5 \pm 0.1$ & $1.1 \pm 0.1$ \\
\hline
\end{tabular}

Note: $* P<0.05$ to intact of 12 -month old; $* * P<0.05$ to intact of 1.5 -month old. 
$\mathrm{CP}$ in them does not change, but at the same time there arises a marked tendency to the decrease of $\mathrm{CP}$ level in sub-cell fraction.

Shifts in the content of products of free-radical oxidation of lipids and proteins in mitochondrial fraction of the femoral muscle of 1.5-month old rats is accompanied by a parallel increase of $\mathrm{SB} / \mathrm{TBA}+$ by $97 \%$ in comparison with its original value (Table). At the same time, this index value in 12-month old animals decreases by $35 \%$ in comparison with the original one.

The presented data demonstrate a fact that clearly expressed signs of oxidative stress are formed in mitochondrial fraction of the femoral muscle of rats in pubertal age after prolonged immobilization. They are demonstrated through the increase of the level of products of free-radical oxidation of lipids and proteins (CP and SB). The increase of SB/TBA+ index, accompanying these changes, reflects the increase of the velocity of usage of carbon products of free-radical oxidation in non-catalytic reactions, connected with formation of adducts with proteins. One of the reasons of this process might be a decrease of effectiveness of utilization of endogenous aldehydes in fermentation pathways in the femoral muscle mitochondria of immobilized pubertal rats that results in metabolic preconditions for formation of the muscle stress damage.

Thus, the age-dependent shifts in utilization effectiveness of endogenous aldehydes in the skeletal muscle mitochondria appear in rats under the conditions of immobilization stress. The reason of this phenomenon might be the change in activity of aldehyde catabolism enzymes, in particular AlDG, AlR and GT $[14,15]$. Taking this into consideration, the activity of these enzymes was investigated in the mitochondria fraction of the femoral muscle in the animals of both age groups, which underwent prolonged immobilization.

The performed investigations showed that activity of NAD-dependent AlDG becomes 8 times as high, and activity NADH-dependent AlR two times as high in mitochondrial fraction of 12-month old rats in comparison with 1.5-month old rats. Gluthathione tranferase activity in rats of the both studied age groups is at the same level.

The obtained data show that the basal activity of mitochondrial enzymes, catalyzing oxidativerenewal transformation of endogenous aldehydes in NAD-dependent reactions in 12-month old rats is significantly higher than in 1.5 -month old rats.
This creates preconditions for the increase of adult animals' muscle resistance to negative effect of oxidative stress under condition of immobilization that is not characteristic of the pubertal rats. However, modulation of these enzymes is possible under the immobilization stress. The above-stated being allowed for we continued investigation of activity of mitochondrial enzymes of catabolism of endogenous aldehydes in the femoral muscle of rats after prolonged immobilization.

The performed investigations have shown that after prolonged immobilization the increase of aldehyde dehydrogenase activity by $223 \%$ and $101 \%$ in mitochondrial fraction of the femoral muscle of 1.5-month old and 12-month old animals is observed compared to that in intact rats of these age groups. At the same time, aldehyde reductase activity in immobilized 1.5-month old animals decreases by $41 \%$ in comparison with its original value. Aldehyde reductase activity in 12-month old rats under the immobilization stress remains unchanged. Gluthatione transferase activity in mitochondrial fraction of the femoral muscle of animals of the both investigated age groups after immobilization remains at the original level.

Thus, an adaptive increase of aldehyde hydrogenase activity in mitochondrial fraction of the femoral muscle of investigated rats under conditions of immobilization stress is observed, that leads to a significant increase of accumulated activity of all investigated enzymes of catabolism of endogenous aldehydes. At the same time, this shift in the pubertal animals is accompanied by a decrease of aldehyde reductase activity in mitochondria. Analyzing the situation with appearance of different changes in activity of $\mathrm{NAD}(\mathrm{H})$-dependent oxidoreductases in 1.5-month old rats, we may presume formation of a specific state of "stress" in them under utilization of carbonyl products of free-radical oxidation, which are intensively generated under immobilization stress.

A comprehensive evaluation of the obtained results allows one to conclude that adaptive shifts aimed at the increase of oxidative-renewal changes of endogenous aldehydes are formed under the conditions of high basal aldehyde dehydrogenase and aldehyde reductase activity in adult sexually-mature animals. As a result, products of free-radical oxidation of proteins (CP, SB and TBA-reactive substances) are not accumulated in the muscle tissue, so the oxidative stress manifestations are absent. 
Due to different character of modulation of mitochondrial aldehyde dehydrogenase and aldehyde reductase in rats of pubertal age, a possibility of catabolism of products of free-radical oxidation is limited. This may lead to the increase in the level of free-radical oxidation of proteins (CP and SB) in the femoral muscle mitochondria of rats. As a result, sensitivity of the animals of this age group to stress damage increases.

Summing up all the above-mentioned facts, one may conclude that catabolism effectiveness of endogenous aldehydes under stimulation of their formation during immobilization stress on the stage of sexual maturation is limited. Similar phenomenon is observed in the myocardium and skeletal muscle as well, that points to its generalized character in organism. Age change of velocity of gene expression of oxidoreductase, catalyzing oxidative-renewal changes of aldehydes in the muscle tissue is a basis for this phenomenon. Sex hormones, which level in pubertal animals is significantly lower than in sexually mature ones, may appear as one of probable factors of gene expression regulation. Change of hormonal secretion promotes the appearance of agedependent differences in the structure of isoenzyme spectrum of the given enzymes in the muscle tissue. This, in its turn, presumes a decrease of general basal activity of mitochondrial aldehyde dehydrogenases and aldehyde reductase and also a change of their response to modulation of the internal medium of muscle cells under the immobilization stress in pubertal age. This results in the increase of oxidative stress factors in the muscle tissue under prolonged immobilization in animals on the stage of sexual maturation, and thus, the increase of its sensitivity to stress damage.

However, the expressed presumption on age modulation of isoenzyme spectrum of aldehyde dehydrogenases and aldehyde reductases in muscles needs the experimental check, that will be the basis of our further investigations.

\section{ОКСИДАТИВНИЙ СТРЕС \\ I ЕНЗИМАТИЧНА СИСТЕМА \\ КАТАБОЛІЗМУ АЛЬДЕГІДІВ \\ У МІТОХОНДРІЯХ М'ЯЗІВ \\ ІММОБІЛІЗОВАНИХ ЩУРІВ \\ ПУБЕРТАТНОГО ВІКУ}

\author{
Амжад Хамдаллах 1 В. В. Давидов², \\ B. М. Швець ${ }^{3}$
}
${ }^{1}$ Харківський національний університет ім. В. Н. Каразіна, Україна;
${ }^{2} Д У$ «Інститут охорони здоров'я дітей та підлітків НАМН України», Харків;
Запорізький державний медичний університет, Україна; e-mail: vaddavydov@mail.ru

Мета роботи - з'ясування особливостей прояву оксидативного стресу i стану ензиматичної системи утилізації ендогенних альдегідів у мітохондріальній фракції скелетних (стегнових) м'язів у щурів пубертатного віку в умовах іммобілізаційного стресу. Дослідження показали, що в іммобілізованих щурів пубертатного віку виникає різноспрямований характер модуляції активності мітохондріальних альдегіддегідрогеназ і альдегідредуктаз, що обмежує можливість ефективного катаболізму карбонільних продуктів вільнорадикального окислення в м'язах. Підтвердженням цього $є$ збільшення в тварин рівня продуктів вільнорадикального окислення протеїнів у мітохондріях скелетних м'язів. Показано, що на етапі статевого дозрівання в щурів підвищується чутливість скелетних м'язів до оксидативного стресу за рахунок модуляції в ньому стану ензиматичної системи утилізації ендогенних альдегідів у мітохондріях.

К л ю ч о в і с л о в а:альдегіддегідрогенази, альдегідредуктази, глутатіонтрансферази, альдегіди, карбонільовані протеїни, шиффові основи, пубертатний вік, оксидативний стрес, іммобілізаційний стрес. 


\section{ОКСИДАТИВНЫЙ СТРЕСС И ЭНЗИМАТИЧЕСКАЯ СИСТЕМА КАТАБОЛИЗМА АЛЬДЕГИДОВ В МИТОХОНДРИЯХ МЫШЦ ИММОБИЛИЗИРОВАННЫХ КРЫС ПУБЕРТАТНОГО ВОЗРАСТА}

\author{
Амжад Хамдаллах 1 В. В. Давыцов², \\ В. Н. Швеи
}
${ }^{1}$ Харьковский национальный университет им. В. Н. Каразина, Украина;
${ }^{2} Г У$ «Институт охраны здоровья детей и подростков НАМН Украины», Харьков;
ЗЗапорожский государственный медицинский университет, Украина; e-mail: vaddavydov@mail.ru

Цель работы - выяснение особенностей проявления оксидативного стресса и состояния энзиматической системы утилизации эндогенных альдегидов в митохондриальной фракции скелетных (бедренных) мышц у крыс пубертатного возраста при иммобилизационном стрессе. Исследования показали, что у иммобилизированных крыс пубертатного возраста возникает разнонаправленный характер модуляции активности митохондриальных альдегиддегидрогеназ и альдегидредуктаз, что ограничивает возможность эффективного катаболизма карбонильных продуктов свободнорадикального окисления в мышцах. Подтверждением этого служит увеличение у животных уровня продуктов свободнорадикального окисления протеинов в митохондриях скелетных мышц. Показано, что на этапе полового созревания у крыс повышается чувствительность скелетных мышц к оксидативному стрессу за счет модуляции состояния в ней энзиматической системы утилизации эндогенных альдегидов в митохондриях.

К л ю че вы е с лов а: альдегиддегидрогеназы, альдегидредуктазы, глутатионтрансферазы, альдегиды, карбонилированные протеины, шиффовы основания, пубертатный возраст, оксидативный стресс, иммобилизационный стресс.

\section{References}

1. Volkova Y. V., Davydov V. V. Effect of immobilization stress on the content of products of free radical oxidation of lipids and proteins in subcellular fractions of the brain of rats of different age. Ukr. Biokhim. Zhurn. 2009;81(2):45-49 (in Russian).

2. Volkova Y. V., Sukhova L. L., Davydov V. V., Goloborodko A. V. Activity of the first line antioxidant defense enzymes in the liver of pubertal rats during stress. Biochemistry (Moscow) Suppl. Series B: Biomed. Chem. 2011;5(4):389-391.

3. Korenev N. M., Nosova E. M. Clinicalhemodynamic parameters of cerebral disorders formation at adolescent with primary arterial hypertony. Pediatry Obstet. Gynecol. 2002;(2):15-18. (In Ukranian).

4. Uchida K. Role of reactive aldehyde in cardiovascular disease. Free Radical. Biol. Med. 2000;28(12):1685-1696.

5. Grabovetskaya E. R., Davydov V. V. Age peculiarities activity of enzymes take part in utilization of aldehydes in heart mitochondria of rats during stress. Probl. Aging. Longevity. 2009;18(2):166-173. (In Russian).

6. Grabovetskaya E. R., Davydov V. V. Activity of enzymes these take part in utilization of aldehydes in the heart of rats of different age during stress. Ukr. Biokhim. Zhurn. 2009;81(1):99-104. (In Russian).

7. Pirozhkov S. V., Panchenko L. F. Role of aldehyde dehydrogenases in the metabolism of malonic dialdehyde in the rat liver. Biochemistry. 1988;53(9):1443-1448. (In Russian).

8. Srivastava S., Liu S. Q., Couklin D. J., Zacarias A., Srivastava S. K., Bhatnagar A. Involvement of aldose reductase in metabolism of atherogenic aldehyde. Chem. Biol. Interact. 2001;130-132(1-3):563-571.

9. Mannervik B., Guthenberg C. Glutathione transferase. Methods Enzymol. 1981;77:231-235.

10. Esterbauer H., Zolner H. Methods for determination of aldehydic lipid peroxidation products. Free Radic. Biol. Med. 1989;(2):197203.

11. Dubinina E. E. Oxidative modification of blood proteins in patients with psychiatric disorders. Voprosy Med. Khimii. 2000;(4):36-47. (In Russian).

12. Chen Che-Hong, Budas G. R., Churchill E. N., Disatnik M. H., Hurley T. D., Mochly-Rosen D. Activation of aldehyde dehydrogenase-2 reduces ischemic damage to the heart. Science. 2008;321(5895):1493-1495.

13. Ji-Zhong Chenh. Accelerated metabolism and exclusion of 4-hydroxynonenal through 
induction of RLIP76 and hGST.8 is an early adaptive response of cells to heat and oxidative stress. J. Biol. Chem. 2001;276(44):41213-41233.

14. Davydov V. V., Dobaeva N. M., Bozhkov A. N. Possible role of alteration of aldehyde's scavenger enzymes during aging. Exp. Gerontol. 2004;39(1):11-16.
15. Davydov V. V., Bozhkov A. I., Kulchitski O. K. Physiological and pathophysiological role of endogenous aldehydes. Saarbrucken: Palmarium Academic Publishing, 2012. 240 p. (In Russian).

Received 16.04.2014 